\title{
The Effect of Climate Change on Variations in Dew Amount in a Paddy Ecosystem of the Sanjiang Plain, China
}

\author{
Yingying Xu, ${ }^{1,2}$ Baixing Yan, ${ }^{3}$ and Jie Tang ${ }^{1}$ \\ ${ }^{1}$ College of Resources and Environment, Jilin University, Qianjin Street, Dist 2699, Changchun 130021, China \\ ${ }^{2}$ Key Laboratory of Songliao Aquatic Environment, Ministry of Education, Jilin Jianzhu University, Xincheng Street, Dist 5088, \\ Changchun 130118, China \\ ${ }^{3}$ Key Laboratory of Wetland Ecology and Environment, Northeast Institute of Geography and Agroecology, \\ Chinese Academy of Sciences, Shengbei Street, Dist 4888, Changchun 130102, China \\ Correspondence should be addressed to Yingying Xu; xuyingying.1019@aliyun.com
}

Received 1 December 2014; Revised 15 February 2015; Accepted 15 February 2015

Academic Editor: Hiroyuki Hashiguchi

Copyright (C) 2015 Yingying Xu et al. This is an open access article distributed under the Creative Commons Attribution License, which permits unrestricted use, distribution, and reproduction in any medium, provided the original work is properly cited.

Due to global warming, a drying and warming trend has been observed over the last 50 years in the Sanjiang Plain of Heilongjiang Province, China, which could significantly affect the condensation of vapor in paddy ecosystems. Dew is a crucial factor in the water and nutrient cycling of farmland ecosystems, and it exerts an important influence on fertilization and other agricultural activities. In order to reveal the effects of global warming on dew variation in a paddy ecosystem, an in situ experiment was conducted in paddy fields in the Sanjiang Plain during the growing seasons of 2011 to 2013. Dew was collected and measured with a poplar stick. The results of correlation analysis between meteorological factors and dew intensity in the paddy ecosystem indicate that the dew point temperature and relative humidity significantly influenced the dew intensity. Based on synchronous meteorological data, a stepwise linear multivariation regression model was established to predict dew amount. The model successfully interpreted the relationship between simulated and measured dew intensity. The results suggest that a warmer and drier climate would lead to a reduction in dew amount because water cannot condense when relative humidity falls below $71 \%$.

\section{Introduction}

Global climate change is significantly altering various environmental variables in many countries around the world. This situation could have important effects that seriously threaten populations as well as agriculture, environment, economy, and industry [1]. Atmospheric water vapor is one of the most important factors in determining the Earth's weather and climate because of its role as a greenhouse gas as well as the large amounts of energy involved in changing water from liquid and solid phases to the gaseous (vapor) phase [2]. As an indicator of water vapor levels in the air, relative humidity $(\mathrm{RH})$ directly affects atmospheric visibility and strongly influences the formation of clouds, fog, and dew. Three sources of water are involved in dew formation in an ecosystem. The dominant one is water vapor in the lower atmosphere (dewfall). The second one originates from the flooded soil (dewrise). The last one is the guttation which is the loss of water and dissolved materials from uninjured plant organs [3-5]. Direct condensation of atmospheric water vapor brings a net gain of water to the soil-plant-water system, compared to guttation from leaves and distillation of soil water [6]. Dew formation is a widespread meteorological and hydrologic phenomenon which can be an important water input in paddy fields [7], and dew also transports nutrients that benefit paddy growth as it condenses on leaves $[3,8]$. Dew can also accelerate the dissolution of foliar fertilizer and pesticides which enhances their absorption via leaf tissue $[9,10]$. Additionally, some of the nutrients in dew can be assimilated by certain fungal or insect pests [11]. Therefore, monitoring the dew formation may help farm workers determine the appropriate concentration and timing for foliar fertilizer applications.

Dew has attracted great interest and has been extensively studied. Experiments have been conducted that the variations in the amounts of dew falling daily or seasonally were observed $[12,13]$. In some studies, dew was estimated by 
a direct weighing method that compared the monitor at the beginning and end of the condensation process $[5,14]$. Monitors such as microlysimeters [15], plywood, synthetic velvet [16], glass plates [17], and polyethylene plates [18, 19] have all been used to monitor dew. These direct methods are considered the most accurate. However, manual collection and evaluation of the monitors are required during the early morning. Therefore, models that are able to calculate dew have been considered [20-22].

Meteorological factors affect dew formation to a great extent. Nilsson stressed that, in humid Kungsbacka and arid Dodoma, dew volume data were correlated with dry bulb temperature, dew point temperature, wind speed, and cloud cover [23]. Atmospheric pressure, wind speed, and direction distinguished dew in different sites in Poland [24]. In the Philippines, dew formation was found to have a significant linear correlation with the nightly minimum vapor-pressure deficit [4]. Dew correlated positively with relative humidity [19]. A high relative humidity is needed to observe dew, but it does not mean that dew amounts exhibit the maximum, during the relative humidity in the air, reach to $100 \%$ [25]. Dew can form only when the temperature of condenser surface is below the dew point temperature. Indeed, the dew point temperature depends on the moisture conditions, and less heat is emitted from underlying surface for dew condensation at a higher relative humidity [26]. The wind speed is a key factor for dew formation. However, the function of wind for dew deposit is complicated. Although the strong wind enhances the heat exchange, this situation may homogenize the temperature quickly and decrease the temperature down below the dew point temperature. Meanwhile, it makes the vapor diffuse rapidly. It is known that wind speed (at $10 \mathrm{~m}$ elevation) greater than $3.0 \mathrm{~m} \cdot \mathrm{s}^{-1}$ significantly decreases collected dew volumes $[27,28]$. Therefore, breeze is beneficial to enhancement of the transition of water vapor and heat loss in horizontal and vertical direction [19]. As a consequence, a mean wind speed as large as $3.5 \mathrm{~m} \cdot \mathrm{s}^{-1}$ is too fast to provide sufficient vapor for the frequent condensation [25]. Models based on meteorological factors such as the relative humidity, temperature, and wind speed can simulate observed dew to a satisfactory extent. This method requires less labor, but no internationally accepted standard model exists for dew observation since the conditions that allow the condensation of vapor are complex. Therefore, a suitable model needs to be constructed for each type of ecosystem.

Northeastern China is one of the areas mostly influenced by global change and has particular climate characteristics. According to the data from 1949, the climate in the area trended to become warming-drying. It was more obvious in summer and autumn and in sensitive areas such as Sanjiang Plain $[29,30]$. The Sanjiang Plain is the largest concentrated area of freshwater wetlands in China. Over the last 50 years, most of the marsh areas have been reclaimed into paddy fields. Large-scale land reclamation severely affects the climate in this region. It has been shown that the annual mean temperature in the Sanjiang Plain has increased by $+1.2^{\circ} \mathrm{C}$ to $+2.3^{\circ} \mathrm{C}$ from 1955 to 1999 [31]. Decreases in annual precipitation have also been observed, falling by $-8.9 \mathrm{~mm} \cdot 10 \mathrm{a}^{-1}$ from
1951 to 2002 [32]; meanwhile, the relative humidity decreased obviously by $5-16 \%$ from 1950 to 1985 . This trend is expected to continue [33]. Based on previous research, the actual dew reached $26 \mathrm{~mm}$ to $31 \mathrm{~mm}$ each year in the paddies of the conservation unit area on the Sanjiang Plain. This accounted for $6.0 \%$ to $9.0 \%$ of the rainfall during the same period [34]. Therefore, dew plays an important role in the water balance of paddy ecosystems, but few studies have focused on the change in dew resulting from climate change. It is hard to distinguish the vapor from the atmosphere or from the flooded soil in a paddy field, and, in the present study, dew is defined as the mixture of dewfall and dewrise. The objectives of this study are to (a) formulate a model based on relative meteorological factors that will predict dew intensity and (b) explore the effect of climate change on dew amount in paddy ecosystems.

\section{Materials and Methods}

2.1. Study Site. The experiment was organized in the Sanjiang Farmland Experimental Station $\left(47^{\circ} 35^{\prime} \mathrm{N}, 133^{\circ} 31^{\prime} \mathrm{E}\right)$ of the Chinese Academy of Sciences in Tongjiang, Heilongjiang Province, Northeast China (Figure 1). The station has an area of 7.13 ha. The elevation is approximately $56 \mathrm{~m}$ above sea level. The Sanjiang Plain is characterized by a typical temperate semihumid continental monsoon climate with four distinctive seasons and a long freezing period. The frostfree period is $115-130 \mathrm{~d}$, the frozen period is approximately $210 \mathrm{~d}$, and the snow period is roughly $120 \mathrm{~d}$. The average annual temperature is $1.9^{\circ} \mathrm{C}$. The average temperature during the experimental period was $15.8^{\circ} \mathrm{C}$. The average total annual sunshine is $2304.3 \mathrm{~h}$, and the annual evaporation is $1257.1 \mathrm{~mm}$. Seasonal variation of wind direction is significant, and the annual average wind speed is $3.6 \mathrm{~m} \cdot \mathrm{s}^{-1}$. The precipitation from June to September is typically 550 to $600 \mathrm{~mm}$ and normally accounts for over $65 \%$ of the annual precipitation [35].

2.2. Methodology. Measurements in the paddy began in midMay and ended in mid-October for two reasons. First, our study focuses on dew which condenses on leaves, and summer to early autumn is the growing season. Second, the dew point temperature $\left(T_{d}\right)$ is below zero after October. Dew was monitored from 2011 to 2013. Polished poplar wood sticks with dimensions of $18 \times 3.5 \times 3.5 \mathrm{~cm}$ (length $\times$ width $\times$ height) were used as monitors. There were five sites used for dew monitoring. Based on isotopic mass conservation to partition quantitatively the contribution of different vapour sources of dew, dew water consisted of a downward flux of water vapor from above the canopy (98\%) and upward fluxes originated from soil evaporation and transpiration of the leaves in the lower canopy (2\%) in a cropland [3]. As to paddy dew, the evaporation of surface water was supposed to take more partition. Dewfall and dewrise will be the focus of this study. For each experiment plot, an observation shelf was set up with two layers, a bottom layer $(5 \mathrm{~cm}$ above surface water level) and a canopy layer. The canopy layer was continually adjusted to the height of the rice canopy. The canopy monitor mainly estimated the dew formed by condensation of atmospheric 


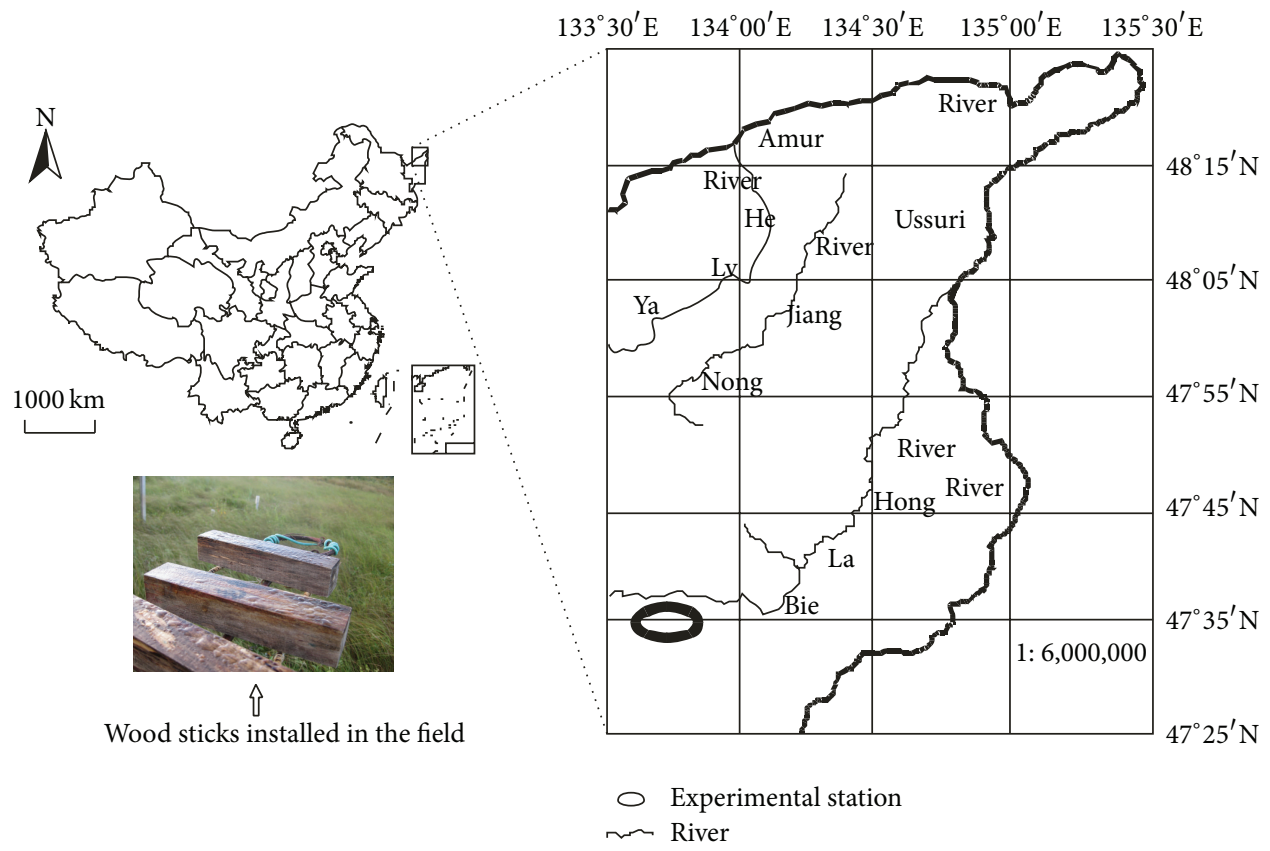

FIgURE 1: Location of the experimental station and the monitors installed in the field.

water vapor, and the lower monitor mainly estimated dew formed from water vapor rising from the surface of the water. The monitors were weighed daily at sunset and sunrise with an electronic balance (accuracy within $0.001 \mathrm{~g}$ ). For each height, three monitors were set up $30 \mathrm{~min}$ after sunset. These monitors were gathered $30 \mathrm{~min}$ before sunrise and weighed again. The actual dew per unit area for each plot was computed as the average of the two heights and the actual dew measurement was computed as the average of five sites. The monitors were left in the paddy during the day to prevent excessive air drying and eliminate the effects of moisture absorption on measuring accuracy $[34,36]$. A total of 70 , 86 , and 75 samples were collected in 2011, 2012, and 2013, respectively.

The leaf area index (LAI) of the paddy was measured using a LAI-2000 Plant Canopy Analyzer (LI-COR, Inc., USA) over a 10-day interval. Distinguishing dew from rain was difficult, so dew was recorded as zero if there was rainfall during the measuring period. Meanwhile, the daily meteorological factors, including air temperature $\left({ }^{\circ} \mathrm{C}\right)\left(T_{a}\right)$, dew-point temperature $\left({ }^{\circ} \mathrm{C}\right)\left(T_{d}\right)$, relative humidity $(\%)(\mathrm{RH})$, wind speed $\left(\mathrm{m} \cdot \mathrm{s}^{-1}\right)\left(V_{\text {night }}\right)$ at $10 \mathrm{~m}$ elevation, total nocturnal net radiative heat loss $\left(\mathrm{MJ} \cdot \mathrm{m}^{-2}\right)\left(R_{n}\right)$, rainfall $(\mathrm{mm})$, and water vapor pressure $(\mathrm{hPa})\left(V_{p}\right)$, were measured at hourly intervals during the condensation period via the MILOS 520 automatic weather station (VAISALA, Finland) at the Sanjiang Paddy Station. RH, $T_{d}, V_{p}, V_{\text {night }}$, and $T_{a}$ were the factors used in the models and all were the mean values for the period of condensation. The dew intensity and the meteorological factors were analyzed using a one-way analysis of variance (ANOVA), and the significance level was set to $P<0.05$.
2.3. Data Analysis and Model Establishment. Dew intensity $(I)$ is defined as the amount of dew that condenses on all the terrestrial objects including plants and soil in unit land area in one night. It represents the ability of condensation. The unit is counted by millimeter.

Dew intensity was calculated with the following formula:

$$
I=\frac{10 \times\left(W_{r}-W_{s}\right)}{S},
$$

where $I$ is the dew intensity $(\mathrm{mm}) ; W_{r}$ is the weight of the condenser before sunrise $(\mathrm{g}) ; W_{s}$ is the weight of the condenser after sunset (g); $S$ is the surface area of the condenser $\left(\mathrm{cm}^{2}\right)$; and 10 is a conversion factor.

Dew amount $(D F)$ is defined as the amount of dew that condenses on all the terrestrial objects including plants and soil in unit land area in a particular period. It represents the quantity of dew, including the amount of dewfall and dewrise. The unit is counted by millimeter. The total dew amount was calculated via the following formulas:

$$
\begin{gathered}
D F=\sum_{i=1}^{n} D F_{i}, \\
D F_{i}=2 \times \operatorname{LAI}_{i} \times \overline{I_{i}} \times D_{i},
\end{gathered}
$$

where $D F$ is the total dew amount $(\mathrm{mm}) ; D F_{i}$ is the dew amount in a particular period $(\mathrm{mm})$; and LAI is the leaf area index. $\mathrm{LAI}_{i}$ is the LAI in a particular period $\left(\mathrm{cm}^{2} \cdot \mathrm{cm}^{-2}\right) ; \overline{I_{i}}$ is the average $I$ in a particular period $(\mathrm{mm})$; and $D$ is the number of dew days. $D_{i}$ is the $D$ in a particular period (days); 2 is a coefficient to account for both sides of the leaf; and 


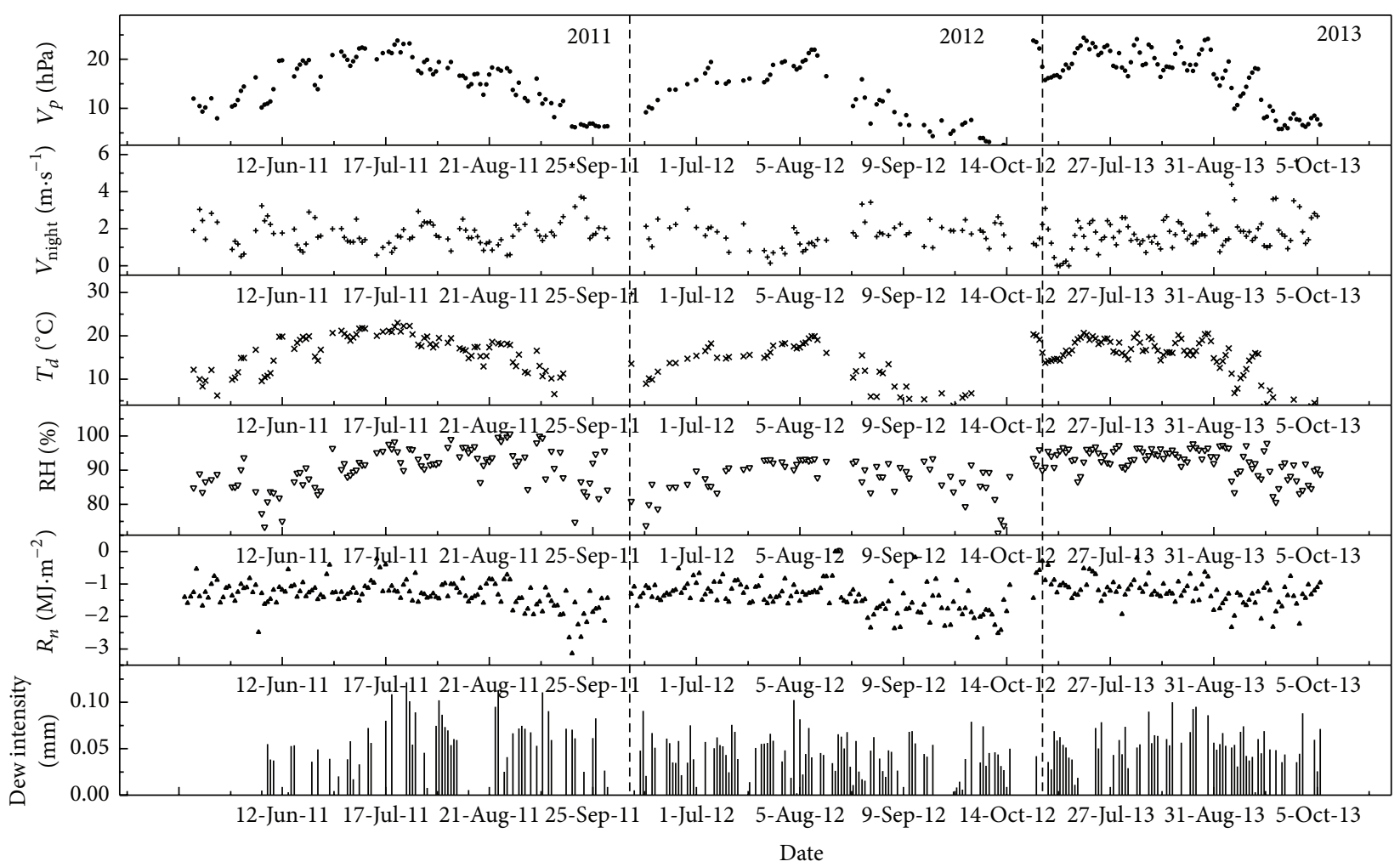

FIGURE 2: Variation of dew-related meteorological factors in the dew days during the experimental period.

$n$ is the time period of measuring LAI $[34,36]$. Statistical analyses were carried out using the SPSS (Statistical Product and Service Solutions) software version 16.0 (USA). To test for a normal distribution of dew intensity, Q-Q probability plots were employed.

In this study, data were subjected to correlation tests. Based on the results of the statistical analysis, a stepwise linear multivariable regression model was chosen as the method to estimate the dew intensity. A $t$-test was used to validate the model. Data from 2011 and 2012 were used to build the model, and data from 2013 were used to verify the model.

\section{Results and Discussion}

3.1. Dew Intensity and Factors. Figure 2 shows the patterns of dew intensity and meteorological factors from 2011 to 2013 in the Sanjiang Plain. All the highest dew intensities were observed in August. The impact of meteorological factors on dew formation can be seen in Figure 2. According to the statistical analyses, the monthly meteorological factors follow a normal distribution pattern. The dew levels in 2011 correspond to higher RH, $T_{a}$, and $V_{p}$. The rainfall was abundant in July and August, resulting in sufficient atmospheric vapor and increased $\mathrm{RH}$ and $V_{p}$ values. Correspondingly, the low dew intensity in May and October was due to the significant $\mathrm{RH}$ deficit which resulted in a decreased $T_{d}$ during these months compared with other months $(P<0.05)$. The $\mathrm{RH}$ values in July and August were significantly higher than in other
TABLE 1: Correlation coefficients between dew intensity and meteorological factors.

\begin{tabular}{lcccccc}
\hline & $R_{n}$ & $\mathrm{RH}$ & $T_{d}$ & $V_{\text {night }}$ & $V_{p}$ & $T_{d}-T_{a}$ \\
\hline $\begin{array}{l}\text { Dew } \\
\text { intensity }\end{array}$ & 0.162 & $0.872^{* *}$ & $0.342^{* *}$ & $-0.510^{* *}$ & $0.366^{* *}$ & $0.850^{* *}$ \\
\hline *** & & & & & \\
\hline
\end{tabular}

${ }^{* *}$ Correlation is significant at the 0.01 level (2-tailed).

months $(P<0.05)$, resulting in increased vapor condensation at night during the rainy season.

The wind speed is another key factor for vapor condensation. Strong wind can enhance heat exchange and homogenize the temperature quickly, which lowers the temperature to below the dew point temperature. Meanwhile, it makes the vapor diffuse rapidly. Breezes enhance the transition of water vapor and heat loss in the horizontal and vertical directions [19]. Figure 2 shows that most of the dew events occurred with wind speeds below $3.1 \mathrm{~m} \cdot \mathrm{s}^{-1}$ and that the largest dew amount occurred with wind speeds around $1.8 \mathrm{~m} \cdot \mathrm{s}^{-1}$.

3.2. Model Establishment. A model to predict dew intensity was built based on the correlation analyses between dew intensity and meteorological factors (Table 1). Dew intensity shows the highest positive Pearson correlation coefficient with RH (0.872) while $T_{d}-T_{a}, V_{\text {night }}, V_{p}$, and $T_{d}$ have coefficients of $0.850,-0.510,0.366$, and 0.342 , respectively. This combined with the tests of normativity suggests that $\mathrm{RH}, T_{d}$, 
TABLE 2: Model summary showing $R^{2}$, adjusted $R^{2}$, and standard error of the estimate.

\begin{tabular}{lcccc}
\hline Model & $R$ & $\begin{array}{c}R \\
\text { squared }\end{array}$ & $\begin{array}{c}\text { Adjusted } R \\
\text { squared }\end{array}$ & $\begin{array}{c}\text { Std. error of } \\
\text { the estimate }\end{array}$ \\
\hline 1 & $0.875^{\mathrm{a}}$ & 0.766 & 0.763 & 0.01081 \\
2 & $0.889^{\mathrm{b}}$ & 0.790 & 0.785 & 0.01029 \\
3 & $0.900^{\mathrm{c}}$ & 0.810 & 0.803 & 0.00986 \\
\hline
\end{tabular}

${ }^{\text {a }}$ Predictors: (constant), $\mathrm{RH}$.

${ }^{\mathrm{b}}$ Predictors: (constant), RH, $T_{d}-T_{a}$.

${ }^{\mathrm{c}}$ Predictors: (constant), RH, $T_{d}-T_{a}, T_{d}$.

Dependent variable: dew intensity.

$V_{p}, T_{d}-T_{a}$, and $V_{\text {night }}$ exhibit linear relationships with dew intensity. Therefore, they were selected as the variables to establish the stepwise linear multivariable regression model.

As shown in Table 2, the correlation coefficients $(R)$ between dew intensity and meteorological factors increased from Models 1 to 3 with more factors included in model. $\mathrm{RH}$ accounted for $76.6 \%$ of the variability in dew intensity. Including $T_{d}-T_{a}$ and $T_{d}$ in the model increased the explanatory power to $79.0 \%$ and $81.0 \%$. $R$ increased to 0.900 in Model 3. Thus, Model 3 showed a better prediction ability for dew intensity. In this case, $\mathrm{RH}, T_{d}$, and $T_{d}-T_{a}$ were selected to predict dew intensity.

In conclusion, Model 3 was chosen for this study. The equation that best predicted the outcome (Table 3 ) can be described by

$$
\begin{array}{r}
I=-0.717+0.8 \mathrm{RH}-0.031\left(T_{d}-T_{a}\right)+0.001 T_{d} \\
\left(R^{2}=0.810\right) .
\end{array}
$$

3.3. Model Validation. The equation was validated as follows. Each coefficient was found to be statistically significant $(P<$ 0.05 ) (Table 3 ). The tolerance of $\mathrm{RH}, T_{d}$, and $T_{d}-T_{a}$ was 0.792 , 0.508 , and 0.602 , respectively. These values were not close to 0 . Variance inflation factor (VIF) values of $\mathrm{RH}, T_{d}$, and $T_{d}-T_{a}$ were $1.263,1.968$, and 1.660 , respectively. These values are not considered high. No collinearity was observed between the predictors.

$R^{2}$, the coefficient of determination, is the squared value of the multiple correlation coefficients. It shows that $76.6 \%$, $79.0 \%$, and $81.0 \%$ of the variation in dew intensity is explained by Models 1 to 3, respectively. As a further measure of the strength of the model fit, the standard errors of the estimate in the model summary table (0.01081, 0.01029, and 0.00986 for Models 1 to 3) are significantly small. A residual is the difference between the observed and model-predicted values of the dependent variable. The residual for a given product is the observed value of the error term for that product. A $P$-P plot of the residuals in Figure 3 is a visual check on the assumption of normality in the error terms. The $P-P$ plotted residuals could be plotted on a $45^{\circ}$ line. The $P$ - $P$ plot indicated that the assumption of normality could not be verified. The plot of residuals showed that the variances of the errors were well scattered based on the predicted values.

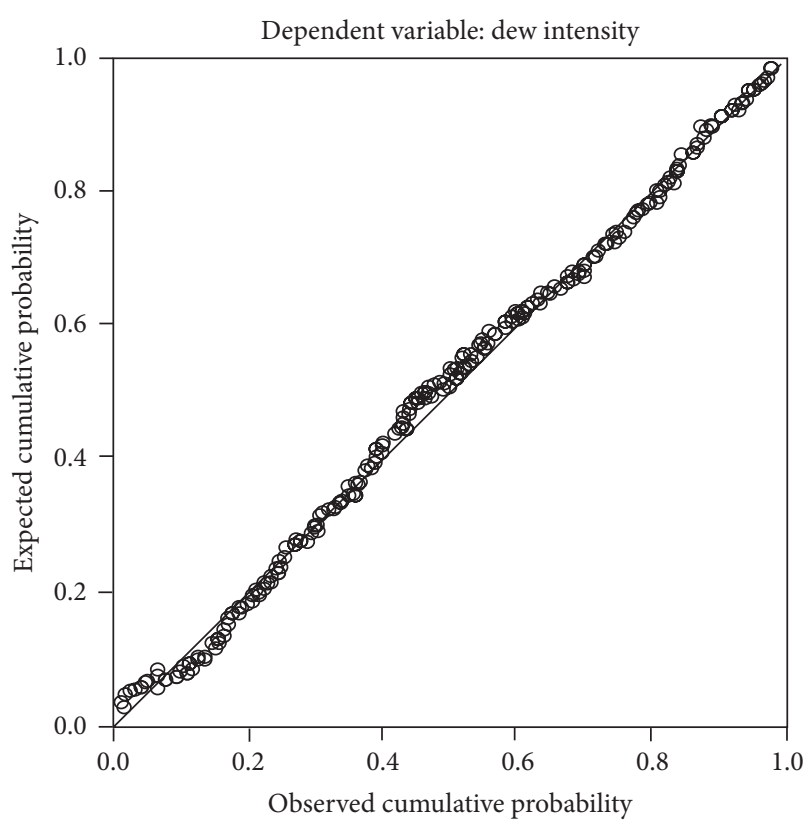

FIgURE 3: Normal P-P plots of regression standardized residual.

Also, the simulated and measured $I$ were not significantly different ( $n=75, P>0.05$ ) (Table 4 ). These results illustrate that this model successfully expressed the relationship between meteorological factors and dew intensity.

3.4. Dew Amount Prediction. As the average global temperature increases, observations show that the regional averaged pan evaporation over some districts has a steady descent trend in the late 50 years, including the United States, the former Soviet Union [38], India [39], Nigeria [40], and east of China [29]. Soil moisture is also reduced in summer over extensive midcontinental regions of both North America and Eurasia in middle and high latitudes [41]. The declining trend in evaporation is consistent with what one would expect from the observed large and widespread decreases in sunlight resulting from increasing cloud coverage and aerosol concentration $[42,43]$. The air relative humidity shows a fluctuant decreasing trend over much of the world [29, 40, $44]$, while wind speed is positively correlated with relative humidity, and wind speed holds downtrend recently $[29,44]$.

For the formation of dew largely depends on the surroundings, temperature, light, relative humidity, and so forth, the models which include meteorological data to calculate dew amount were established around the world. The correlated parameters in the models were shown in Table 5.

From the models mentioned above, in general, there existed positive correlation between dew amounts and relative humidity $(\mathrm{RH})$, water vapor pressure $\left(V_{p}\right)$, net radiative loss $\left(R_{n}\right)$, soil moisture, and dew-point temperature $\left(T_{d}\right)$, while wind speed $\left(V_{\text {night }}\right)$, cloud cover, and air temperature $\left(T_{a}\right)$ were negatively correlated to dew amounts, respectively. Therefore, the meteorological conditions under the climate 
TABle 3: Coefficients of dependent variable (dew intensity).

\begin{tabular}{|c|c|c|c|c|c|c|c|}
\hline \multirow[t]{2}{*}{ Model } & \multicolumn{2}{|c|}{ Unstandardized coefficients } & \multirow{2}{*}{$\begin{array}{c}\text { Standardized } \\
\text { coefficients } \\
\text { Beta } \\
\end{array}$} & \multirow[t]{2}{*}{$t$} & \multirow[t]{2}{*}{ Sig. } & \multicolumn{2}{|c|}{ Collinearity statistics } \\
\hline & $B$ & Std. error & & & & Tolerance & VIF \\
\hline \multicolumn{8}{|l|}{1} \\
\hline (Constant) & -0.142 & 0.003 & & 21.054 & 0.000 & & \\
\hline $\mathrm{RH}$ & 0.200 & 0.001 & 0.471 & 7.399 & 0.000 & 1.000 & 1.000 \\
\hline \multicolumn{8}{|l|}{2} \\
\hline (Constant) & 0.052 & 0.007 & & 8.015 & 0.000 & & \\
\hline $\mathrm{RH}$ & -0.513 & 0.001 & 0.520 & 8.111 & 0.000 & 0.943 & 1.061 \\
\hline$T_{d}-T_{a}$ & 0.600 & 0.004 & -0.203 & -3.170 & 0.002 & 0.943 & 1.061 \\
\hline \multicolumn{8}{|l|}{3} \\
\hline (Constant) & -0.717 & 0.012 & & 2.387 & 0.018 & & \\
\hline $\mathrm{RH}$ & 0.080 & 0.001 & 0.461 & 6.654 & 0.000 & 0.792 & 1.263 \\
\hline$T_{d}-T_{a}$ & -0.031 & 0.005 & -0.304 & -3.830 & 0.000 & 0.602 & 1.660 \\
\hline$T_{d}$ & 0.001 & 0.000 & 0.183 & 2.119 & 0.035 & 0.508 & 1.968 \\
\hline
\end{tabular}

${ }^{\mathrm{a}}$ Dependent variable: dew intensity.

TABLE 4: Results of the independent samples test.

\begin{tabular}{lcccccccr}
\hline & $F$ & Sig. & $t$ & df & Sig. (2-tailed) & $\begin{array}{c}\text { Mean } \\
\text { difference }\end{array}$ & $\begin{array}{c}\text { Std. error } \\
\text { difference }\end{array}$ & $\begin{array}{c}\text { 95\% confidence interval of the } \\
\text { difference } \\
\text { Lower }\end{array}$ \\
$\begin{array}{l}\text { Equal variances } \\
\text { assumed }\end{array}$ & 1.785 & 0.187 & 6.179 & 52.00 & 0.000 & 0.03194 & 0.00517 & 0.02153 \\
$\begin{array}{l}\text { Equal variances } \\
\text { not assumed }\end{array}$ & & & 6.179 & 44.678 & 0.000 & 0.03194 & 0.00517 & 0.02153 \\
\hline
\end{tabular}

TABle 5: Parameters in models at Sanjiang Plain and at reported sites.

\begin{tabular}{|c|c|c|c|c|c|c|c|c|}
\hline Site & $\begin{array}{l}\text { China, } \\
\text { Sanjiang } \\
\text { Plain }\end{array}$ & $\begin{array}{l}\text { Philippines, } \\
\text { Los Banos }\end{array}$ & $\begin{array}{l}\text { Netherlands, } \\
\text { Wageningen }\end{array}$ & Israel, Negev & $\begin{array}{l}\text { Morocco, } \\
\text { Mirleft }\end{array}$ & $\begin{array}{l}\text { USA, Iowa } \\
\text { State }\end{array}$ & $\begin{array}{l}\text { Saudi Arabia, } \\
\text { Dhahran }\end{array}$ & $\begin{array}{c}\text { France, } \\
\text { Ajaccio and } \\
\text { Bordeaux }\end{array}$ \\
\hline References & This study & {$[4]$} & {$[10]$} & {$[15]$} & [18] & {$[20]$} & {$[22]$} & [37] \\
\hline $\mathrm{RH}(\%)$ & $\sqrt{ }$ & & & $\sqrt{ }$ & $\sqrt{ }$ & $\sqrt{ }$ & $\sqrt{ }$ & $\sqrt{ }$ \\
\hline$T_{a}\left({ }^{\circ} \mathrm{C}\right)$ & $\sqrt{ }$ & & $\sqrt{ }$ & $\sqrt{ }$ & $\sqrt{ }$ & $\sqrt{ }$ & $\sqrt{ }$ & $\sqrt{ }$ \\
\hline$V_{\text {night }}(\mathrm{m} / \mathrm{s})$ & & $\sqrt{ }$ & & $\sqrt{ }$ & $\sqrt{ }$ & $\sqrt{ }$ & & $\sqrt{ }$ \\
\hline$V_{p}($ hpa $)$ & & $\sqrt{ }$ & & & & & & \\
\hline $\begin{array}{l}\text { Cloud cover }(\mathrm{N}, \\
\text { in octas) }\end{array}$ & & & & & $\sqrt{ }$ & $\sqrt{ }$ & $\sqrt{ }$ & $\sqrt{ }$ \\
\hline$T_{d}\left({ }^{\circ} \mathrm{C}\right)$ & $\sqrt{ }$ & & & & $\sqrt{ }$ & $\sqrt{ }$ & & \\
\hline$R_{n}\left(\mathrm{MJ} / \mathrm{m}^{2}\right)$ & & & $\sqrt{ }$ & $\sqrt{ }$ & & & & \\
\hline $\begin{array}{l}\text { Soil moisture } \\
(\%)\end{array}$ & & & & $\sqrt{ }$ & & & & \\
\hline
\end{tabular}

$* \sqrt{ }$ stands for the parameter in the model.

change (except wind speed) are not suitable for dew formation. Heavy dew may threaten the dispersal of pollen, leading to the high ghost rate during the flowering period [4]. It has been found that removing dew in the early morning during the flowering stage can improve the grain yield [45]. It is good for grain with the decreasing dew. However, dew is collected for household use [18] and serves as source of water for small animals, plants, and biological crusts in arid region [15].
Decline of dew and rainfall is supposed to lead to a weaker hydrological cycle, which connects directly to availability and quantity of fresh water.

As to our research site, Zhao and Zeng [46] found that the meteorological conditions in the Sanjiang Plain have changed dramatically during the past 50 years. The air temperature has increased and the relative humidity has declined [29]. The rate of change in the Sanjiang Plain exceeded the global 
TABle 6: The average decrement of dew amount due to climate changes.

\begin{tabular}{|c|c|c|c|c|c|}
\hline \multicolumn{6}{|c|}{ Dew amount $(\mathrm{mm})$} \\
\hline \multirow{2}{*}{$\mathrm{RH}(\%)$} & \multicolumn{5}{|c|}{$T_{a}\left({ }^{\circ} \mathrm{C}\right)$} \\
\hline & 20 & 21 & 22 & 23 & 24 \\
\hline 80 & 0.0 & 1.6 & 1.6 & 1.6 & 1.7 \\
\hline 79 & -2.9 & -1.3 & -1.3 & -1.3 & -1.2 \\
\hline 78 & -5.9 & -4.3 & -4.3 & -4.3 & -4.2 \\
\hline 77 & -8.8 & -7.2 & -7.2 & -7.2 & -7.1 \\
\hline 77 & -8.8 & -7.2 & -7.2 & -7.2 & -7.1 \\
\hline 76 & -11.7 & -10.2 & -10.2 & -10.2 & -10.1 \\
\hline 75 & -14.6 & -13.1 & -13.1 & -13.2 & -13.0 \\
\hline 74 & -17.5 & -16.2 & -16.2 & -16.2 & -16.1 \\
\hline 73 & -20.5 & -19.1 & -19.1 & -19.1 & -19.0 \\
\hline 72 & -23.4 & -22.1 & -22.1 & -22.1 & -21.9 \\
\hline 71 & -26.4 & -25.0 & -25.0 & -25.0 & -24.9 \\
\hline 70 & -29.3 & -27.9 & -27.9 & -27.9 & -27.8 \\
\hline
\end{tabular}

TABLE 7: Monthly total dew intensity of bottom and canopy in paddy.

\begin{tabular}{|c|c|c|c|c|c|c|c|c|c|c|}
\hline \multicolumn{11}{|c|}{ Dew intensity $(\mathrm{mm})$} \\
\hline \multirow{3}{*}{ Year } & \multirow{2}{*}{\multicolumn{2}{|c|}{ June }} & \multirow{2}{*}{\multicolumn{2}{|c|}{ July }} & \multirow{2}{*}{\multicolumn{2}{|c|}{$\begin{array}{l}\text { Month } \\
\text { August }\end{array}$}} & \multirow{2}{*}{\multicolumn{2}{|c|}{ September }} & & \\
\hline & & & & & & & & & \multicolumn{2}{|c|}{ October } \\
\hline & Bottom & Canopy & Bottom & Canopy & Bottom & Canopy & Bottom & Canopy & Bottom & Canopy \\
\hline 2011 & 0.379 & 0.361 & 0.784 & 1.024 & 0.856 & 1.142 & 0.723 & 1.147 & & \\
\hline 2012 & 0.669 & 0.727 & 0.823 & 1.115 & 0.986 & 1.112 & 0.513 & 0.709 & 0.321 & 0.607 \\
\hline 2013 & & & 0.608 & 1.02 & 0.854 & 1.45 & 0.921 & 1.371 & 0.112 & 0.202 \\
\hline
\end{tabular}

rate of climate change. According to Liu [47], the relative humidity decreased by $5-16 \%$ from 1950 to 1985 , and this trend is expected to continue. As a result, the average annual relative humidity is expected to decrease from $80 \%$ to $70 \%$ in the Sanjiang Plain, and the average annual air temperature is expected to increase from 20 to $24^{\circ} \mathrm{C}$. Table 6 shows the average decrement of dew amount in the paddies. For example, when the average air temperature increases to $22^{\circ} \mathrm{C}$, the average relative humidity is expected to decrease to $75 \%$. According to the model equation (1), the average daily dew intensity would decline by $0.036 \mathrm{~mm}$ under these conditions. From 2008 to 2013, dew fell on an average of 70 days. The average LAI during growth periods were $0.02,2.12,4.37,4.83$, 3.32 , and $1.10 \mathrm{~cm}^{2} \cdot \mathrm{cm}^{-2}$ from May to October, respectively. If the number of days with dew and the LAI did not change, dew amount would be reduced by $13.1 \mathrm{~mm}$ under these conditions. Dew amount was $26-31 \mathrm{~mm} \cdot \mathrm{yr}^{-1}$ in the period of $2005-2012$ [34]. If the average relative humidity decreased from $80 \%$ to $71 \%$, there would be almost no dew in the paddies of the Sanjiang Plain at any time. The results can be used to guide land managers in decisions related to the concentration and timing of sprayed foliar fertilizer and pesticide applications.

3.5. Contribution of Dewfall versus Dewrise. The canopy and bottom monitors mainly estimated the dew formed by condensation of dewfall and dewrise, respectively. As shown in Table 7, dew intensity varied with the height and was found in canopy to be higher than that in the bottom. The ratio of intensity in canopy and bottom was varied with time. The contribution of dewfall versus dewrise was almost same in June, and the intensity of canopy was more than twice as much as the bottom in October. In order to discriminate the different vapor sources of dew, stable isotope $\left(\delta^{18} O\right.$ and $\left.\delta D\right)$ of dewfall and dewrise should be monitored in the further study.

\section{Conclusion}

The regression equation between meteorological factors and dew intensity was established as $I=-0.717-0.031\left(T_{d}-\right.$ $\left.T_{a}\right)+0.8 \mathrm{RH}+0.001 T_{d}$. The accuracy degree of the simulation of this model was good. If the climate in the Sanjiang Plain becomes warmer and drier, condensation of water vapor is made significantly less likely. If the climate continues to warm, a significant decrease in dew amount is anticipated. Dew could not form when the relative humidity decreased from $80 \%$ to $71 \%$.

\section{Conflict of Interests}

The authors declare that there is no conflict of interests regarding the publication of this paper. 


\section{Acknowledgments}

The authors gratefully acknowledge funding support from the National Nature Science Foundation of China (41401229). They express their gratitude to the Sanjiang Mire Farmland Experimental Station of the Chinese Academy of Sciences for providing meteorological data. They are indebted to the senior scientists of their team for their critical reading, kind remarks, and relevant suggestions. They thank LetPub (http://www.letpub.com/) for its linguistic assistance during the preparation of this paper.

\section{References}

[1] H. Yavuz and S. Erdoğan, "Spatial analysis of monthly and annual precipitation trends in Turkey," Water Resources Management, vol. 26, no. 3, pp. 609-621, 2012.

[2] A. A. Abu-Taleb, A. J. Alawneh, and M. M. Smadi, "Statistical analysis of recent changes in relative humidity in Jordan," American Journal of Environmental Sciences, vol. 3, no. 2, pp. 75-77, 2007.

[3] X. F. Wen, X. Lee, X. M. Sun et al., "Dew water isotopic ratios and their relationships to ecosystem water pools and fluxes in a cropland and a grassland in China," Oecologia, vol. 168, no. 2, pp. 549-561, 2012.

[4] W. Luo and J. Goudriaan, "Dew formation on rice under varying durations of nocturnal radiative loss," Agricultural and Forest Meteorology, vol. 104, no. 4, pp. 303-313, 2000.

[5] A. F. G. Jacobs, B. G. Heusinkveld, and S. M. Berkowicz, "Dew deposition and drying in a desert system: a simple simulation model," Journal of Arid Environments, vol. 42, no. 3, pp. 211-222, 1999.

[6] S. Y. He and K. Richards, "The role of dew in the monsoon season assessed via stable isotopes in an alpine meadow in Northern Tibet," Atmospheric Research, vol. 151, pp. 101-109, 2015.

[7] S. P. Singh, P. Khare, K. M. Kumari, and S. S. Srivastava, "Chemical characterization of dew at a regional representative site of North-Central India," Atmospheric Research, vol. 80, no. 4, pp. 239-249, 2006.

[8] Y. Y. Xu, B. X. Yan, and H. Zhu, "Leaf dew contributes nutrients to paddies and improves rice growth," Acta Agriculturae Scandinavica Section B: Soil and Plant Science, vol. 63, no. 2, pp. 97-106, 2013.

[9] S. Munne-Bosch, S. Nogues, and L. Alegre, "Diurnal variations of photosynthesis and dew absorption by leaves in two evergreen shrubs growing in Mediterranean field conditions," New Phytologist, vol. 144, no. 1, pp. 109-119, 1999.

[10] A. F. G. Jacobs, B. G. Heusinkveld, and S. M. Berkowicz, "Passive dew collection in a grassland area, The Netherlands," Atmospheric Research, vol. 87, no. 3-4, pp. 377-385, 2008.

[11] W. Schuh, "Influence of interrupted dew periods, relative humidity, and light on disease severity and latent infections caused by Cercospora kikuchii on soybean," Phytopathology, vol. 83, no. 1, pp. 109-113, 1993.

[12] M. Muselli, D. Beysens, M. Mileta, and I. Milimouk, "Dew and rain water collection in the Dalmatian Coast, Croatia," Atmospheric Research, vol. 92, no. 4, pp. 455-463, 2009.

[13] A. Zangvil, "Six years of dew observations in the Negev Desert, Israel," Journal of Arid Environments, vol. 32, no. 4, pp. 361-371, 1996.
[14] G. J. Kidron, I. Herrnstadt, and E. Barzilay, "The role of dew as a moisture source for sand microbiotic crusts in the Negev Desert, Israel," Journal of Arid Environments, vol. 52, no. 4, pp. 517-533, 2002.

[15] A. F. G. Jacobs, B. G. Heusinkveld, and S. M. Berkowicz, "A simple model for potential dewfall in an arid region," Atmospheric Research, vol. 64, no. 1-4, pp. 285-295, 2002.

[16] G. J. Kidron, "Altitude dependent dew and fog in the Negev Desert, Israel," Agricultural and Forest Meteorology, vol. 96, no. 1-3, pp. 1-8, 1999.

[17] G. J. Kidron and A. Starinsky, "Chemical composition of dew and rain in an extreme desert (Negev): cobbles serve as sink for nutrients," Journal of Hydrology, vol. 420-421, pp. 284-291, 2012.

[18] I. Lekouch, K. Lekouch, M. Muselli, A. Mongruel, B. Kabbachi, and D. Beysens, "Rooftop dew, fog and rain collection in southwest Morocco and predictive dew modeling using neural networks," Journal of Hydrology, vol. 448-449, pp. 60-72, 2012.

[19] Y. H. Ye, K. Zhou, L. Y. Song, J. H. Jin, and S. L. Peng, "Dew amounts and its correlations with meteorological factors in urban landscapes of Guangzhou, China," Atmospheric Research, vol. 86, no. 1, pp. 21-29, 2007.

[20] A. C. Madeira, K. S. Kim, S. E. Taylor, and M. L. Gleason, "A simple cloud-based energy balance model to estimate dew," Agricultural and Forest Meteorology, vol. 111, no. 1, pp. 55-63, 2002.

[21] J. S. Zhang, Y. Q. Wu, and Z. Li, “Test and research of precipitation intercepted by groundwater and condensation in desert pool of North area of Shaanxi," Soil and Water Conservation, vol. 19, no. 5, pp. 124-126, 2005.

[22] P. Gandhidasan and H. I. Abualhamayel, "Modeling and testing of a dew collection system," Desalination, vol. 180, no. 1-3, pp. 47-51, 2005.

[23] T. Nilsson, "Initial experiments on dew collection in Sweden and Tanzania," Solar Energy Materials and Solar Cells, vol. 40, no. 1, pp. 23-32, 1996.

[24] K. Klimaszewska, C. Sârbu, Z. Polkowska et al., "Application of linear discriminant analysis to the study of dew chemistry on the basis of samples collected in Poland (2004-2005)," Central European Journal of Chemistry, vol. 7, no. 1, pp. 20-30, 2009.

[25] Y. Y. Xu, B. X. Yan, and Y. D. Guo, "Measurement and analysis of formation conditions of dew in Carex lasiocarpa marsh," Wetland Science, vol. 7, no. 2, pp. 155-161, 2009.

[26] N. Takenaka, H. Soda, K. Sato et al., "Difference in amounts and composition of dew from different types of dew collectors," Water, Air, and Soil Pollution, vol. 147, no. 1-4, pp. 51-60, 2003.

[27] M. Muselli, D. Beysens, J. Marcillat, I. Milimouk, T. Nilsson, and A. Louche, "Dew water collector for potable water in Ajaccio (Corsica Island, France)," Atmospheric Research, vol. 64, no. 14, pp. 297-312, 2002.

[28] D. Beysens, I. Milimouk, V. Nikolayev, M. Muselli, and J. Marcillat, "Using radiative cooling to condense atmospheric vapor: a study to improve water yield," Journal of Hydrology, vol. 276, no. 1-4, pp. 1-11, 2003.

[29] H. C. Zuo, D. L. Li, Y. Q. Hu, Y. Bao, and S. H. Lü, “Characteristics of climatic trends and correlation between pan-evaporation and environmental factors in the last 40 years over China," Chinese Science Bulletin, vol. 50, no. 12, pp. 1235-1241, 2005.

[30] F. H. Sun, S. Y. Yang, and P. S. Chen, "Climatic warming-drying trend in Northeastern China during the last 44 years and its effects," Chinese Journal of Ecology, vol. 24, no. 7, pp. 751-755, 2005 (Chinese). 
[31] M.-H. Yan, W. Deng, and X.-H. Ma, "Climate variation in the sanjiang plain disturbed by large scale reclamation during the last 45 years," Acta Geographica Sinica, vol. 56, no. 2, pp. 170179, 2001 (Chinese).

[32] Z. Q. Luan, G. X. Zhang, W. Deng, J. M. Hu, and D. M. Zhou, "Study on the changes of air temperature and precipitation in the last 50 years in the sanjiang plain," Journal of Arid Land Resources and Environment, vol. 21, no. 11, pp. 39-43, 2007 (Chinese).

[33] X. T. Liu, "Radiation balance and microclimatic features of marsh in the Sanjiang Plain," Chinese Geographical Science, vol. 1, no. 4, pp. 347-358, 1991.

[34] Y. Y. Xu, B. X. Yan, Z. Q. Luan, and H. Zhu, "Dewfall variation by large-scale reclamation in Sanjiang Plain," Wetlands, vol. 32, no. 4, pp. 783-790, 2012.

[35] Z. J. Jia, C. C. Song, and L. Sun, "The study on latent and sensible heat flux over mire in the Sanjiang Plain," Wetland Science, vol. 4, no. 1, pp. 13-20, 2006.

[36] B. X. Yan and Y. Y. Xu, "Method exploring on dew condensation monitoring in wetland ecosystem," Procedia Environmental Sciences, vol. 2, pp. 123-133, 2010.

[37] D. Beysens, M. Muselli, V. Nikolayev, R. Narhe, and I. Milimouk, "Measurement and modelling of dew in island, coastal and alpine areas," Atmospheric Research, vol. 73, no. 1-2, pp. 1-22, 2005.

[38] T. C. Peterson, V. S. Golubev, and P. Y. Groisman, "Evaporation losing its strength," Nature, vol. 377, no. 6551, pp. 687-688, 1995.

[39] N. Chattopadhyay and M. Hulme, "Evaporation and potential evapotranspiration in India under conditions of recent and future climate change," Agricultural and Forest Meteorology, vol. 87, no. 1, pp. 55-73, 1997.

[40] O. M. Akinbode, A. O. Eludoyin, and O. A. Fashae, “Temperature and relative humidity distributions in a mediumsize administrative town in southwest Nigeria," Journal of Environmental Management, vol. 87, no. 1, pp. 95-105, 2008.

[41] S. Manabe and R. T. Wetherald, "Large-scale changes of soil wetness induced by an increase in atmospheric carbon dioxide," Journal of the Atmospheric Sciences, vol. 44, no. 8, pp. 1211-1236, 1987.

[42] V. Ramanathan, P. J. Crutzen, J. T. Kiehl, and D. Rosenfeld, "Aerosols, climate, and the hydrological cycle," Science, vol. 294, no. 5549, pp. 2119-2124, 2001.

[43] M. L. Roderick and G. D. Farquhar, "The cause of decreased pan evaporation over the past 50 years," Science, vol. 298, no. 5597, pp. 1410-1411, 2002.

[44] Y. H. Jin, S. H. Lian, D. W. Zhou, J. B. Xu, and C. Peng, "Study on change of relative humidity in semiarid region under global climate change," Journal of Northeast Normal University (Natural Science Edition), vol. 41, no. 4, pp. 134-138, 2009 (Chinese).

[45] J. C. Lin, X. H. Tian, G. X. Yin, J. H. Tang, and Z. G. Yang, "Artificially regulaton the flowering time of CMS lines in Indica hybrid rice seed production," Scientia Agricultura Sinica, vol. 41, no. 8, pp. 2474-2479, 2008 (Chinese).

[46] M. Zhao and X. Zeng, "A theoretical analysision the local climate change induced by the change of landuse," Advances in Atmospheric Sciences, vol. 19, no. 1, pp. 45-62, 2002.

[47] X. T. Liu, "Radiation balance and basic microclimate features of the Sanjiang Plain," Scientia Geographica Sinica, vol. 8, no. 2, pp. 132-133, 1988 (Chinese). 

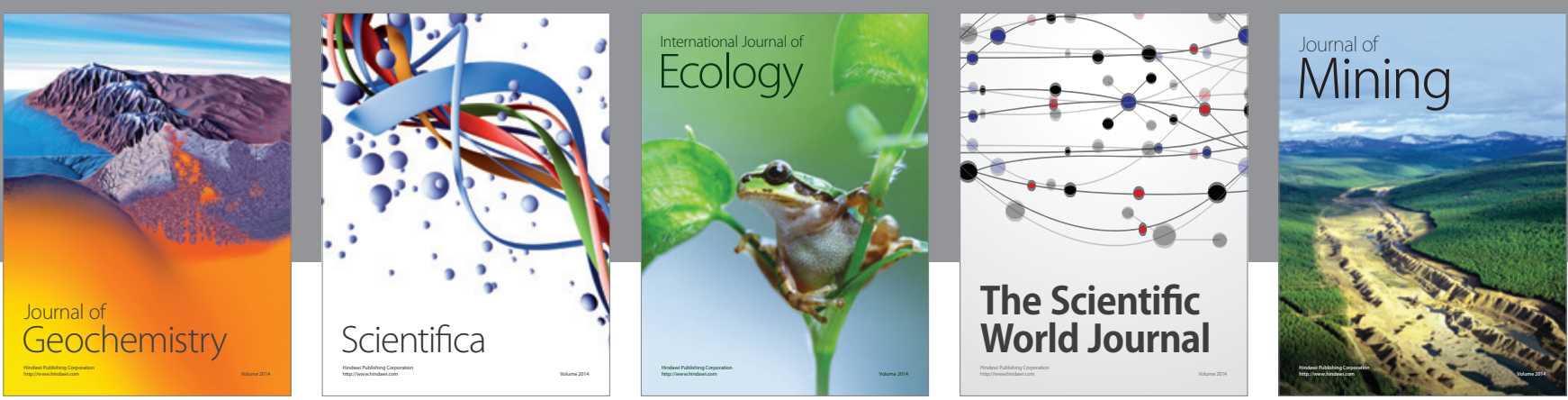

The Scientific World Journal
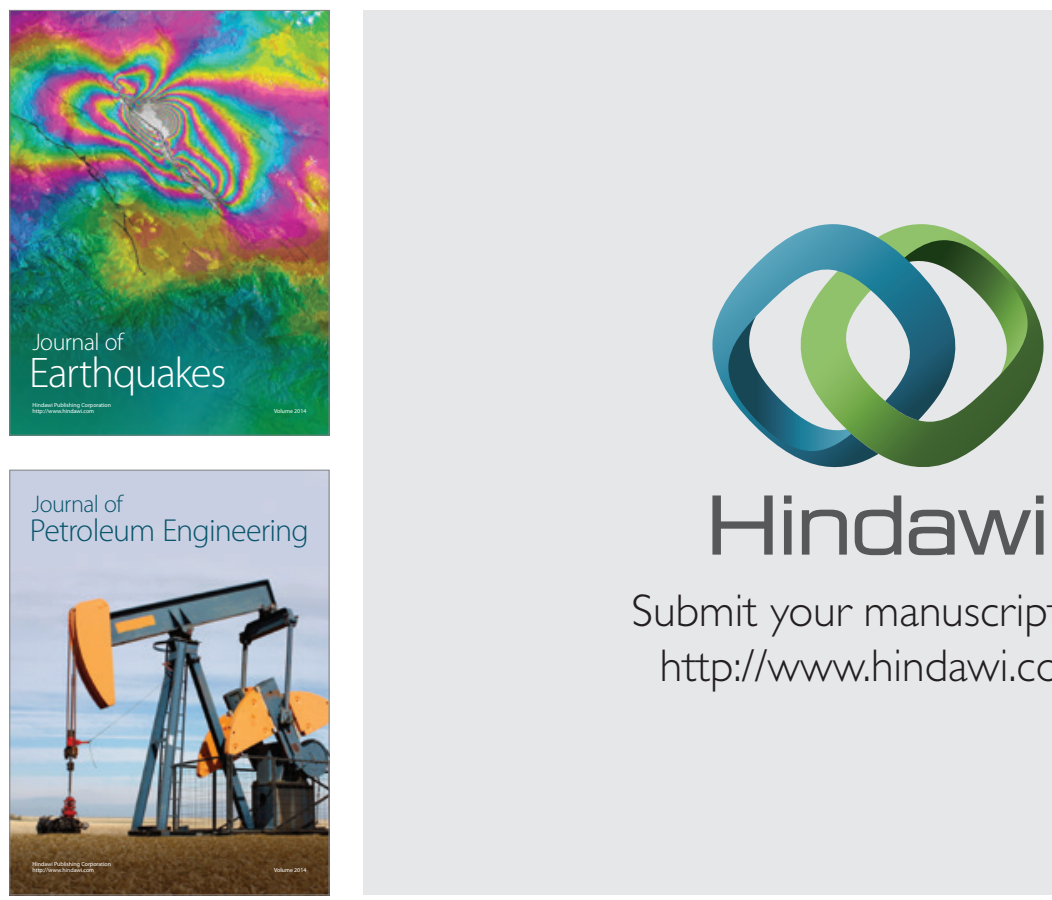

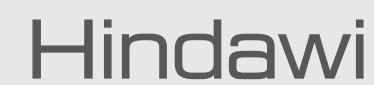

Submit your manuscripts at

http://www.hindawi.com
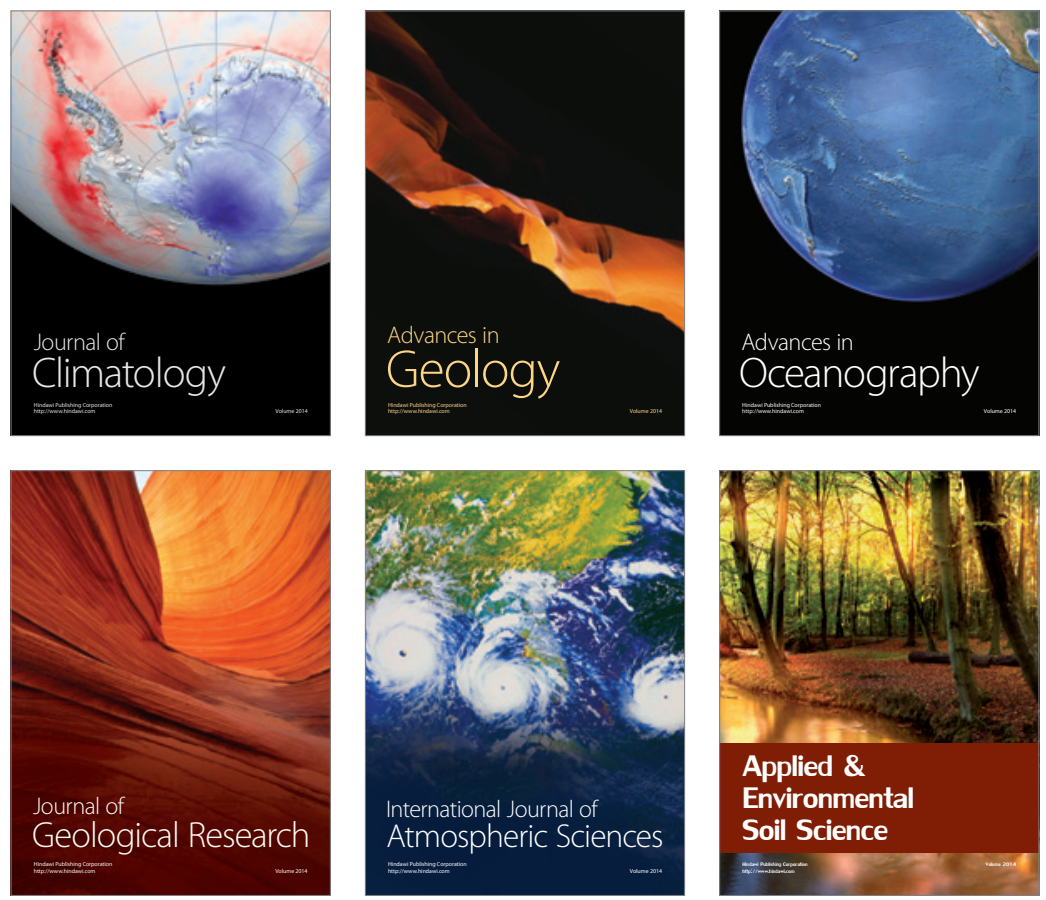
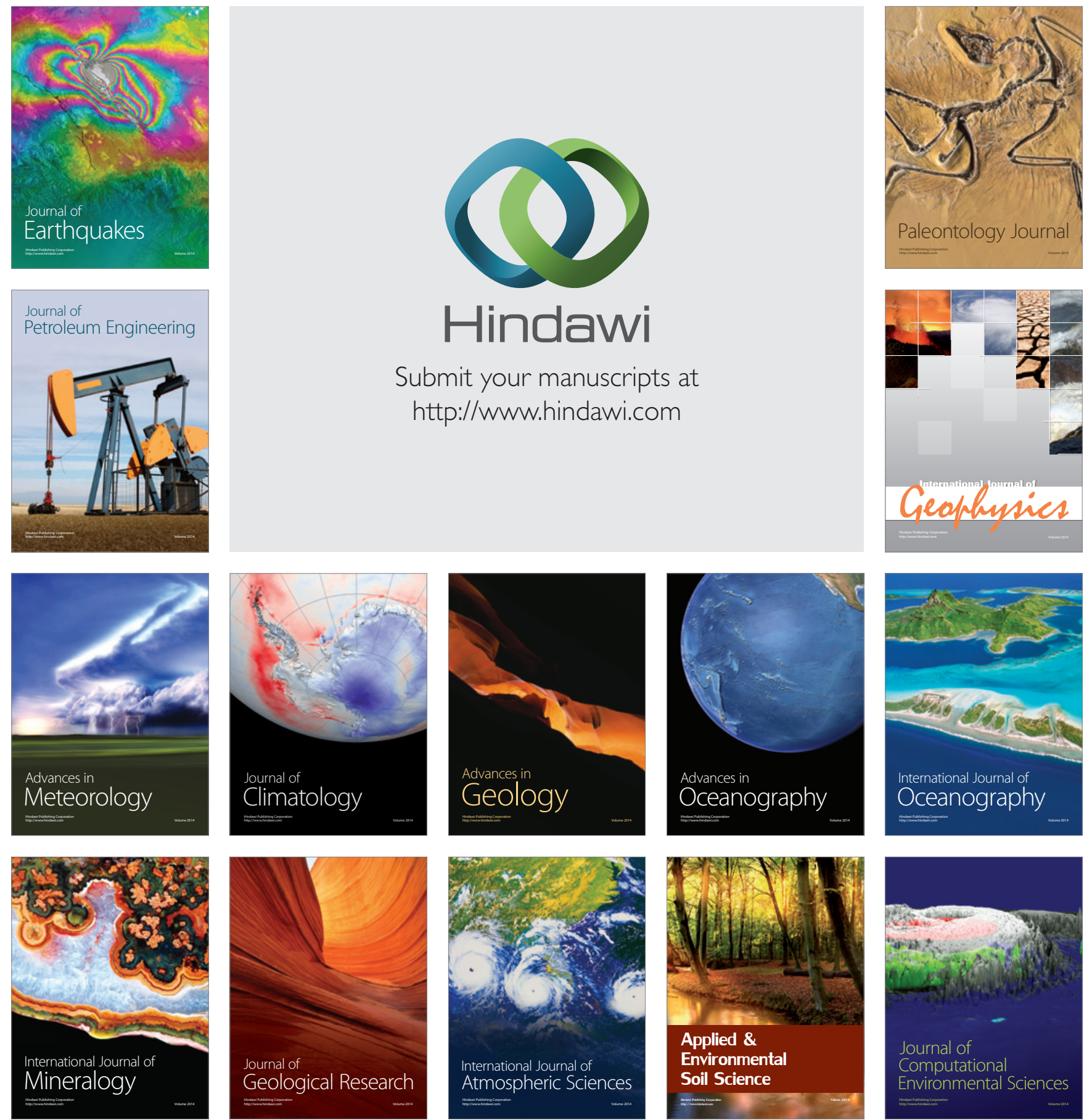